\title{
PERAN PONDOK PESANTREN DALAM MENINGKATKAN KEMANDIRIAN SANTRI DI PONDOK PESANTREN NURROHMAN AL-BURHANY PURWAKARTA
}

Neng Latipah

IKIP SILIWANGI

latifahneng28@yahoo.co.id

\begin{abstract}
ABSTRAK
Penelitian ini menelaah peran pondok pesantren dan kemandirian santri, permasalahan penelitian adalah bagaimana peran pondok pesantren dalam meningkatkan kemandirian santri. Berangkat dari keberbedaan santri-santri dan dengan asal keluarga yang berbeda-beda pula, maka sikap kemandiriannya pun akan berbeda tergantung bagaimana kelurga dalam mendidiknya. maka ada kewajiban dari Pondok Pesantren dalam meningkatkan kemandirian santri tersebut, agar mereka dapat hidup dan tinggal jauh dari orangtuanya. Penelitian ini bertujuan untuk mengetahui gambaran kondisi Pondok Pesantren Nurrohman Al-Burhany Purwakarta, untuk mengetahui bagaimana peran Pondok Pesantren dalam meningkatkan kemandirian santrinya di Pondok Pesantren Nurrohman Al-Burhany Purwakarta dan juga untuk mengetahui faktor-faktor apa saja yang menjadi penghambat dalam meningkatkan kemandirian santri di pondok pesantren Nurrohman Al-Burhany Purwakarta. Teori yang digunakan dalam penelitian ini adalah konsep PLS, Santri, Pondok Pesantren, Tipologi Pondok Pesantren dan Kemandirian. Dalam penelitian ini peneliti menggunakan metode deskriptif dengan pendekatan kualitatif. Data dikumpulkan melalui wawancara, observasi dan dokumentasi. Adapun yang menjadi populasi penelitiannya adalah pondok pesantren Nurrohman AlBurhany Purwakarta dan sampelnya adalah 3 guru dan 3 pengurus dan 7 santri. Hasil penelitian menunjukan bahwa Pondok Pesantren mempunyai peranan yang sangat penting dalam meningkatkan kemandirian santri, dalam hal ini dapat terlihat dari perbedaan antara awal pertama masuk pondok pesantren dan setelah lama tinggal dipondok pesantren. Sikap kemandirian santri ditunjukan dengan selalu melaksanakan kewajiban piketnya, santri dapat disiplin dan tepat waktu, dan tidak tergantung pada orang lain.
\end{abstract}

Kata kunci : Santri, pondok pesantren, dan kemandirian.

\section{PENDAHULUAN}

Salah satu tujuan pendidikan nasional adalah kemandirian. hal ini tercantum dalam

Undang-Undang Sistem Pendidikan Nasional (UU Sisdiknas No. 20/2003) dikemukakan:

Tujuan Pendidikan Nasional, meningkatkan potensi peserta didik agar menjadi manusia yang beriman dan bertakwa kepada Tuhan Yang Maha Esa, berakhlak mulia, sehat, berilmu, cakap, kreatif, mandiri, dan menjadi warga Negara yang demokratis serta bertanggungjawab (Sunarty, 2016, p. 153) 
Pondok pesantren merupakan bagian dari sistem Pendidikan Nasional yang memiliki fokus tidak hanya pada ilmu pengetahuan umum tetapi juga ilmu agama. Pesantren mengajarkan santri bahwa dalam melakukan kegiatan pun harus berawal dari kesadaran sendiri, tanpa pamrih, serta lepas dari tekanan pihak lain sekalipun orang tua, kyai atau bahkan ustadz/ustadzah. Hal ini terlihat jelas dari beberapa peraturan dan sanksi di pondok pesantren yang secara sengaja diadakan untuk menunjang terciptanya kepatuhan dan kemandirian santri dalam melaksanakan kehidupannya sehari-hari, walaupun tetap saja semua itu kembali kepada kepribadian masing-masing santri dan kecerdasan emosi yang dimilikinya (Krisnatuti, Herawati \& Dini, 2011, p. 148).

Kemandirian merupakan aspek yang berkembang dalam diri setiap individu, yang bentuknya sangat beragam, tergantung pada proses perkembangan dan proses belajar yang dialami masing-masing individu. Menurut Driyarkara (Sugito, 2016; Sunarty 2016, p. 153) mengemukakan bahwa kemandirian merupakan kekuatan internal individu yang diperoleh melalui proses individuasi. Oleh karena itu, kemandirian mengandung pengertian memiliki suatu penghayatan/ semangat untuk menjadi lebih baik dan percaya diri, mengelola pikiran untuk menelaah masalah dan mengambil keputusan untuk bertindak, disiplin dan tanggung jawab serta tidak bergantung kepada orang lain.

Studi pendahuluan dan observasi terhadap pondok pesantren Nurrohman Al-Burhany Jl. Kapten Halim Gg. Sumba Kp. Bogas Kidul Kec. Pasawahan Purwakarta terdapat fenomena yang berhubungan dengan kemandirian santri dalam kehidupan di pondok pesantren. Berangkat dari keberbedaan santri-santri dan dengan asal keluarga yang berbeda-beda pula, maka sikap kemandiriannya pun akan berbeda tergantung bagaimana kelurga dalam mendidiknya. Ketika anak itu di masukkan kesebuah Pondok Pesantren maka ada kewajiban dari Pondok Pesantren dalam meningkatkan kemandirian santri tersebut, agar mereka dapat hidup dan tinggal jauh dari orangtuanya. Contoh dalam meningkatkan kemandirian santri dengan cara mendidik santri untuk bisa memasak, merapihkan tempat tidur, mencuci pakaian secara sendiri dan belajar mandiri lainnya. Hal ini dapat terlihat dari diadakannya piket yang dapat mengajarkan santri-santrinya untuk dapat bersikap mandiri, diadakannya perlombaan memasak yang dilaksakan pada bulan Dzulhijjah dan pondok pesantren ini juga memiliki peraturannya sendiri yaitu : setiap santri hanya diperbolehkan pulang ketika lebaran idul fitri dan bulan mulud saja, dan 
setiap santri boleh dikunjungi orang tua hanya 1 (satu) kali dalam 3 (tiga) bulan dan kegiatan lainnya yang akan dapat meningkatkan kemandirian santri. Dengan adanya piket, peraturan dan kegiatan tersebut Pondok Pesantren berharap dapat meningkatkan sedikit demi sedikit kemandirian santrinya.

\section{LANDASAN TEORI}

Pendidikan masyarakat atau pendidikan non formal merupakan setiap kegiatan terorganisasi dan sistematis, di luar sistem persekolahan yang mapan, dilakukan secara mandiri atau merupakan bagian penting dari kegiatan yang lebih luas, yang sengaja dilakukan untuk melayani peserta didik tertentu didalam mencapai tujuan belajarnya. (Sudjana, 2010, p. 21)

\section{Santri}

Kata santri menurut Kamus Bahasa Indonesia berarti “orang yang mendalami agama Islam" kemudian "orang yang beribadat dengan sungguh-sungguh" orang yang shaleh. Dalam (Koswara, 2014) Santri juga diidentikkan dengan kata susastri (sansekerta) yang artinya pelajar agama, pelajar yang selalu membawa kitab ajaran suci (agama). Pada zaman pengaruh Hindu Budha di Nusantara sebutan ini lebih dikenal dengan cantrik, dimana para cantrik berdiam diri dalam sebuah asrama bersama sang guru dalam beberapa lama untuk memperdalam ilmu keagamaan.

Menurut (Maksum, 2003) Secara genetic santri di pesantren dapat dikelompokkan pada dua kelompok besar, yaitu : santri mukim dan santri kalong. Santri mukim adalah santri yang datang dari tempat yang jauh sehingga ia tinggal dan menetap di pondok (asrama) pesantren. Sedangkan santri kalong adalah santri yang berasal dari wilayah sekitar pesantren sehingga mereka tidak memerlukan untuk tinggal dan menetap di pondok, mereka bolak-balik dari rumahnya masing-masing.

\section{Pondok Pesantren}

\section{Pengertian Pondok Pesantren}

Pondok pesantren merupakan bagian dari sistem Pendidikan Nasional yang memiliki fokus tidak hanya pada ilmu pengetahuan umum tetapi juga ilmu agama. Pesantren mengajarkan santri bahwa dalam melakukan kegiatan pun harus berawal dari kesadaran 
sendiri, tanpa pamrih, serta lepas dari tekanan pihak lain sekalipun orang tua, kiai atau bahkan ustadz/ustadzah. Hal ini terlihat jelas dari beberapa peraturan dan sanksi di pondok pesantren yang secara sengaja diadakan untuk menunjang terciptanya kepatuhan dan kemandirian santri dalam melaksanakan kehidupannya sehari-hari, walaupun tetap saja semua itu kembali kepada kepribadian masing-masing santri dan kecerdasan emosi yang dimilikinya (Krisnatuti, Herawati, \& Dini, 2011, p. 148).

\section{Tipologi Pondok Pesantren}

Secara umum pesantren dapat diklasifikasikan menjadi dua, yakni pesantren salaf atau tradisional dan pesantren khalaf atau modern. Sebuah pesantren disebut salaf jika dalam kegiatanpembelajarannya semata-mata berdasarkan pada pola-pola pengajaran klasik atau lama, yakni berupa pengajian kitab kuning dengan metode pembelajaran tradisional serta belum dikombinasikan dengan pola pendidikan modern. Sedangkan pesantren khalaf atau modern adalah pesantren yang di samping tetap dilestarikannya unsur-unsur utama pesantren, memasukkan juga ke dalamnya unsur-unsur modern ditandai dengan sistem klasikal atau sekolah dan adanya materi ilmu-ilmu umum dalam muatan kurikulumnya. Pada pesantren ini sistem sekolah dan adanya ilmu-ilmu umum digabungkan dengan pola pendidikan pesantren klasik. Dengan demikian pesantren modern merupakan pendidikan pesantren yang diperbaharui atau dipermodern pada segi-segi tertentu untuk disesuaikan dengan sistem sekolah (Maksum, 2003, p. 7 sampai 8).

\section{Kemandirian}

\section{Pengertian Kemandirian}

Menurut Hetherington dalam Spencer dan Kass (1976, Rahmah 2004; Retnowati (2008) menyatakan bahwa kemandirian ditunjukkan dengan adanya kemampuan untuk mengambil inisiatif, kemampuan untuk mengatasi masalah, penuh ketekunan, memperoleh kepuasan dari usahanya serta berkeinginan mengerjakan sesuatu tanpa bantuan orang lain.

\section{Faktor yang mempengaruhi kemandirian}

Menurut Hurlock (1991) dalam jurnal Retnowati (2008) menyebutkan lima faktor yang mempengaruhi kemandirian, yaitu: (1) keluarga: misalnya perlakuan ibu terhadap anak, 
(2) sekolah: perlakuan guru dan teman sebaya, (3) media komunikasi massa: misalnya majalah, koran, televisi dan sebagainya, (4) agama: misalnya sikap terhadap agama yang kuat, (5) pekerjaan atau tugas yang menuntut sikap pribadi tertentu.

\section{METODE PENELITIAN}

Dalam penelitian ini peneliti menggunakan metode deskriptif dengan pendekatan kualitatif. Menurut Creswell dalam Darmadi (2014, p. 287), menyebutkan bahwa pendekatan kualitatif adalah suatu proses penelitian pemahaman yang berdasarkan pada metodologi yang menyelidiki suatu fenomena sosial dan masalah manusia. Pada pendekatan ini, peneliti membuat suatu gambaran kompleks, meneliti kata-kata, laporan terinci dari pandangan responden, dan melakukan studi pada situasi yang alami.

Teknik pengumpulan data melalui wawancara, observasi, dan dokumentasi. Dan penelitian ini dilakukan di Pondok Pesantren Nurrohman Al-Burhany Jl. Kapten Halim Gg. Sumba Kp. Bongas Kidul Kecamatan Pasawahan Kabupaten Purwakarta. Populasi merupakan penggeneralisasian berupa subjek/objek yang diteliti untuk dipelajari dan kemudian diambil kesimpulannya dan yang menjadi populasi penenlitian ini guru/pengurus dan santri Pesantren Nurrohman Al-Burhany Jl. Kapten Halim Gg. Sumba Kp. Bongas Kidul Kecamatan Pasawahan Kabupaten Purwakarta. Sedangkan sampel adalah sebagian dari populasi yang dijadikan sebagai objek/subjek penelitian dan untuk menentukan sampelnya penulis mengambil 3 orang guru dan 3 orang pengurus dan 7 orang santri.

\section{HASIL DAN PEMBAHASAN}

\section{HASIL}

\section{Pertama, Kondisi Pondok Pesantren Nurrohman Al-Burhany Purwakarta}

Hasil dari penelitian ini menemukan bahwa Pondok Pesantren Nurrohman Al-Burhany mempunyai 2 program yaitu : (1). Program Pesantren; Program Pesantren terdiri dari : Program kelas Tahfidz dan Program kelas kitab kuning. (2). Program Umum; program umum terdiri dari : belajar berwiarusaha yang kesejahteraan keluarga dan rumah tangga seperti pertukangan, perikanan, pertanian, masak dan lain sebagainya. Dan belajar retorika da'wah (Tamrinan), qiroatul Qur'an, menghafal barjanji, batshul kutub, tahlil dan 
lain sebagainya. Dan adapun santri dipondok Pondok Pesantren Nurrohman Al-Burhany terdiri dari santri mukim dan santri kalong.

Tabel 1. Materi pembelajaran di Ponpes Nurrohman Al-Burhany

\begin{tabular}{|c|c|c|}
\hline Kelas Tahfidz & Kelas Kitab & Kelas Mutaqoddim \\
\hline $\begin{array}{ll}\text { Materi Pembelajaran : } \\
- & \text { Al-Qur'an } \\
- & \text { Safinah } \\
- & \text { Ta'lim Muta'alim } \\
- & \text { Wiridan } \\
- & \text { Do'a Wudhu } \\
- & \text { Istigosah } \\
- & \text { Akhlak } \\
- & \text { Nasoihul Ibad } \\
- & \text { Praktek Shalat } \\
- & \text { Tajwid }\end{array}$ & $\begin{array}{ll}\text { Materi Pembelajaran : } \\
\text { - } & \text { Safinah } \\
\text { - } & \text { Ta'lim Muta'alim } \\
\text { - } & \text { Nasoihul Ibad } \\
\text { - } & \text { Jurumiah } \\
\text { - } & \text { Wiridan } \\
\text { - } & \text { Do'a Wudhu } \\
\text { - } & \text { Syahadataen } \\
\text { - } & \text { Istigosah } \\
\text { - } & \text { Tijan } \\
\text { - } & \text { Matan Majmu } \\
\text { - } & \text { Kaelani } \\
\text { - } & \text { Ryiyadul Badi'ah } \\
\text { - } & \text { Tanqihul Qoul } \\
\text { - } & \text { Akhlak } \\
\text { - } & \text { Praktek Shalat } \\
\text { - } & \text { Tajwid }\end{array}$ & $\begin{array}{ll}\text { Materi Pembelajaran : } \\
\text { - } & \text { Tafsir Jalalain } \\
\text { - } & \text { Tsanusi } \\
\text { - } & \text { Ryiyadul Badi'ah } \\
\text { - } & \text { Fathul Qorib } \\
\text { - } & \text { Nihayatuz Zain } \\
\text { - } & \text { Tajwid Al Burhan } \\
\text { - } & \text { Durotun Nasihin } \\
\text { - } & \text { Alfiyah } \\
\text { - } & \text { Ta'lim Muta'alim } \\
\text { - } & \text { Nasoihul Ibad } \\
\text { - } & \text { Mabade Awwaliyah } \\
\text { - } & \text { Hikam }\end{array}$ \\
\hline
\end{tabular}

Kedua, Peran Pondok Pesantren Nurrohman Al-Burhany Purwakarta dalam meningkatkan kemandirian santri

Pondok pesantren Nurrohman Al-Burhany Purwakarta mempunyai peranan dalam meningkatkan kemandirian santrinya. Peran pondok pesantren dalam meningkatkan kemandirian dapat terkontrol dengan baik, karena dalam waktu 24 jam santriawan dan santriawati berada dalam lingkungan Pondok Pesantren, sehingga memungkinkan itu semua dapat tertanam pada diri santrinya tersebut.

Pembentukan perilaku kemandirian dilakukan dengan kegiatan-kegiatan yang bersifat individual seperti mencuci pakaian sendiri, mengatur keuangan secara sendiri, membersihkan kamar tidur sendiri dan memasak dengan sendiri pula. Sementara itu, santriawan dan santriawati Pondok Pesantren Nurrohman Al-Burhany Purwakarta sebagian besar sudah mampu bersikap mandiri, terlihat dari santriawan dan santriawati dapat melakukan kegiatan-kegiatan yang telah disebutkan diatas dengan baik. 
Ketiga, faktor-faktor penghambat dalam meningkatkan kemandirian santri di pondok pesantren Nurrohman Al-Burhany Purwakarta.

Berdasarkan observasi dan wawancara peneliti, dari beberapa peran pondok pesantren, ada beberapa faktor penghambat dalam meningkatkan kemandirian santrinya di Pondok Pesantren Nurrohman Al-Burhany Purwakarta yaitu : 1). Kebiasaan dan kepribadian yang belum dapat atau bisa beradaptasi dengan keadaan lingkungan dan kebiasaan yang ada di Pondok Pesantren; 2). Banyaknya kebiasaan-kebiasaan di rumah dibawa ke Pondok Pesantren; 3). Tidak mengenali kebutuhan diri dalam hal segala sesuatu; 4). Masih merasa bahwa perkataan seniornya tidak sesuai dengan perbuatannya; dan 5). Masih tergantung kepada orangtua.

\section{PEMBAHASAN}

Pola pendidikan yang diselenggarakan dipesantren cukup beragam. Namun demikian, fungsi yang diembannya sama, yakni mendidik dan menagajrkan ilmu-ilmu agama Islam, sebagai upaya mewujudkan manusia yang tafaqquh fi al-din.kesamaan tersebut dapat dilihat dari jenis-jenis mata aji yang diajarkan di Pesantren. Hampir seluruh Pesantren di tanah air mengajarkan mata aji yang sama, yang terkenal dengan ilmu-ilmu keislaman, yang meliputi Al-Qur'an (tajwid, tafsir dan ilmu tafsir), Al-Hadits, Aqidah/Tauhid, Akhlak/Tasawuf, Fiqih dan Ushul Fiqih, Bahasa Arab (Nahwu, Sharaf, Mantiq dan Balaghah) serta Tarikh/ Sejarah Islam (Maksum, 2003).

Pondok pesantren sangat terkenal dengan kepatuhan santrinya. Kepatuhan dapat diartikan sebagai kecenderungan atau kerelaan seseorang untuk memenuhi dan menerima permintaan, baik yang berasal seorang pemimpin atau yang bersifat mutlak sebagai sebuah tata tertib atau perintah (McKendry, 2009; Krisnatuti, Herawati, \& Dini, 2011) bahwa Hasil penelitian menunjukan bahwa sebagian besar santri masih memiliki tingkat kepatuhan dalam kategori kurang baik. Maksud dari kategori kurang baik disini karena ada sebagian santri yang masih suka melanggar tata tertib atau peraturan yang berada di Pondok Pesantren Nurrohman Al-Burhany salah satunya yaitu santri hanya diperbolehkan pulang ketika lebaran idul fitri dan bulan mulud saja, tapi pada kenyataannya masih ada yang pulang kekampung halamannya diluar dari bulan yang 
sudah ditentukan. Dan itu pun kadang ketua pondok pesantren tidak mengetahui kepulangan santri tersebut.

Selain dari kepatuhan, kehidupan pondok pesantren juga terkenal dengan kemandirian santrinya. Kemandirian merupakan aspek yang berkembang dalam diri setiap individu, yang bentuknya sangat beragam, tergantung pada proses perkembangan dan proses belajar yang dialami masing-masing individu. Menurut Driyarkara (Sugito, 2013; Sunarty; 2016) mengemukakan bahwa kemandirian merupakan kekuatan internal individu yang diperoleh melalui proses individuasi. Oleh karena itu, kemandirian mengandung pengertian memiliki suatu penghayatan/ semangat untuk menjadi lebih baik dan percaya diri, mengelola pikiran untuk menelaah masalah dan mengambil keputusan untuk bertindak, disiplin dan tanggung jawab serta tidak bergantung kepada orang lain.

Menurut Hurlock (1991; Retnowati, 2008) menyebutkan lima faktor yang mempengaruhi kemandirian, yaitu: (1) keluarga: misalnya perlakuan ibu terhadap anak, (2) sekolah: perlakuan guru dan teman sebaya, (3) media komunikasi massa: misalnya majalah, koran, televisi dan sebagainya, (4) agama: misalnya sikap terhadap agama yang kuat, (5) pekerjaan atau tugas yang menuntut sikap pribadi tertentu. Di Pondok Pesantren Nurrohman Al-Burhany Purwakarta masih terdapat beberapa faktor yang menghambat kemandirian santrinya yaitu Kebiasaan dan kepribadian yang belum dapat atau bisa beradaptasi dengan keadaan lingkungan dan kebiasaan yang ada di Pondok Pesantren, Banyaknya kebiasaan-kebiasaan di rumah dibawa ke Pondok Pesantren, Tidak mengenali kebutuhan diri dalam hal segala sesuatu, Masih merasa bahwa perkataan seniornya tidak sesuai dengan perbuatannya dan Masih tergantung kepada orangtua.

\section{KESIMPULAN}

Berdasarkan pemaparan dan hasil penelitian yang telah penulis uraikan di atas, dapat diambil disimpulan bahwa peran pondok pesantren dalam meningkatkan kemandirian santri pondok pesantren Nurrohman Al-Burhany. Peran yang dilakukan pondok pesantren untuk meningkatkan sikap kemandirian santri yaitu dengan diadakannya piket atau kegiatan-kegiatan yang dapat menumbuhkan atau meningkatkan kemandirian 
santrinya, tetapi ada beberapa faktor yang menjadi penghambat dalam meningkatkan kemandirian santri diantaranya yaitu masih bergantungnya pada orangtua walau hal tersebut masih bisa dianggap dalam taraf kecil yang mungkin sebenarnya santri dapat menanganinya dengan sendiri.

\section{DAFTAR PUSTAKA}

damanhuri, a., mujahidin, e., \& hafidhuddin, d. (2013). inovasi pengelolaan pesantren dalam menghadapi persaingan di era globalisasi. ta'dibuna jurnal pendidikan islam, 18.

darmadi, h. (2014). metode penelitian pendidikan dan sosial. bumi kahatulistiwa : alfabeta. Drs Maksum, M. (2003). Pola pembelajaran di pesantren. departemen agama RI.

Koswara, R. (2014). manajemen pelatihan life skill dalam upaya pemberdayaan santri di pondok pesantren. BANDUNG: STKIP SILIWANGI .

krisnatuti, d., Herawati, T., \& dini, r. n. (2011). hubungan antara kecerdasan emosi dengan kepatuhan dan kemandirian santri. Jur.ilm. Kel dan Kons, 148.

Maksum. (2003). pola pembelajaran di pesantren. jakarta: direktorat jenderal kelembagaan agama islam departemen agama R.I.

retnowati, y. (2008). pola komunikasi orang tua dalam membentuk kemandirian anak (studi kasus di kota yogjakarta). jurnal komunikasi, 202.

Sudjana, D. (2010). Pendidikan Nonformal. bandung.

sunarty, k. (2016). hubungan pola asuh orangtua dan kemandiriananak. journal of EST, 153. 